Politics in Central Europe (ISSN: 1801-3422)

Vol. 12, No. 1

DOI: $10.1515 /$ pce-2016-0002

\section{State Civilisation: The \\ Statist Core of Vladimir Putin's Civilisational Discourse and Its Implications for Russian Foreign Policy'}

\author{
FABIAN LINDE
}

\begin{abstract}
The essay examines Vladimir Putin's civilisational discourse, which arose in earnest with the publication of his presidential campaign articles in 2012. It argues that what makes Putin's rendering of Russia's civilisational identity distinctive is its strongly emphasized Statism, understood as a belief in the primacy of the state. This suggests that while his endorsement of a distinct civilisational identity represents an important conceptual turn as regards how national identity is articulated, there are also significant lines of continuity with previous presidential periods, given that state primacy has been at the heart of Putin's political agenda since the very beginning of his presidential career. This detail also reveals a great deal about the political rationale behind Putin's commitment to a Russian civilisational identity. It provides the government with a theoretical justification of an illiberal political course. There are important implications for foreign policy-making as well. In relation to the West, there is an attempt to limit its normative reach by depicting liberal values as less than universal. In regional affairs, Russia is attempting to legitimate its involvement in the near abroad on civilisational grounds. The loose definition of 'co-patriots' as foreign nationals experiencing some affinity with Russia gives it plenty of leeway in this regard. Lastly, Russia has petitioned for Ukraine's neutrality based on the argument that the country is straddling a civilisational fault line.
\end{abstract}

Keywords: civilisational discourse, national identity, foreign policy, Statism, Russia

\title{
Introduction
}

At the onset of Vladimir Putin's third period as president, which began in 2012, the political analyst Nikolai Zlobin perceptively observed that the world was witnessing the arrival of a new Putin who markedly differed from the previous

1 This paper was supported by Institutional support for lonfterm conceptional development of reserch organization 2015 by the Department of Politology and International Relations of the University of West Bohemia, Faculty of Philosophy and Arts. 
one(s). Zlobin's observation had reference to a palpable shift in priorities attached to Putin's public political profile. "If, for the purposes of discussion," he wrote, "the first Presidency can be said to have been about politics, and the second about the economy, then the third is about ideology. Putin 3.0 is the president of values" (Zlobin 2012). Or, as Zlobin put it more succinctly, "the main objective and aims of [Putin] 3.0 are ideological" (Zlobin 2012).

For all its sweeping assertions, Nikolai Zlobin's observation about the increasing importance of values and ideology in Putin's public image did have a great deal of validity and constituted a timely remark on something which has almost become a truism since then. Today, it is widely recognized that emphasizing the uniqueness of Russia's cultural heritage and promoting its 'traditional values' are central concerns for the federal government. Moreover, political choices are being made that demonstrate the fact that ideology in many cases gains the upper hand over both economic concerns and considerations relating to diplomatic convenances.

One of the signature features of this development has been Vladimir Putin's adoption of a civilisational model for framing Russia's national identity. During Dmitry Medvedev's presidency it chiefly used to be Sergey Lavrov, Russia's long-standing Minister of Foreign Affairs, who was the one among the top politicians to conceptualize world politics in accordance with a multicivilisational approach, flanked by Medvedev's advocacy of Russia as an integral part of European civilisation. In recent years, however, this civilisational discourse has taken on a more insular character with Vladimir Putin's promotion of a self-contained Russian civilisational identity. The latter trend began with the presidential campaign articles that were published in his name in January and February 2012. In his articles, Putin made overt reference to both a "civilisational model [tsivilizatsionnaia model']" (Putin 2012a) and a Russian "civilisational identity [tsivilizatsionnaia identichnost']" (Putin 2012 b). His commitment to this civilisational identity did not end, however, with the publication of these articles. During the last few years, he has continued to make public statements that confirm not only the enduring significance of the basic idea of multiple civilisations, but also the importance of Russia having a distinct civilisational identity.

While this can be said to have been a new departure when it comes to the general political direction of Vladimir Putin's public profile, there were also considerable lines of continuity with previous periods. Upon closer examination, this becomes even clearer, especially when one considers exactly how the offered civilisational model was being conceptualised. Putin has for a long time been identified as a dedicated Statist and a state-centric political outlook can indeed be traced back to the very beginning of his presidential career. ${ }^{2}$ Given that a distinguishing feature of Putin's civilisational discourse was and is the strong

2 For a discussion of this aspect of Vladimir Putin's profile, see (Hill - Gaddy 2013). 
emphasis that is being placed on the state in Russian history and society, the conclusion can be drawn that there is a great deal of continuity with Putin 1.0 and 2. 0 . This detail makes it possible to nuance and qualify somewhat Nikolai Zlobin's observation quoted above. It also enables us to identify the political motivation behind the adoption of the civilisational model itself. In fact, the evidence suggests that the heightened interest on the part of the government in matters concerning cultural values and national identity is motivated by an effort to strengthen the state's position in society. A definition of Russian national identity that singles out the state as central assists the government in consolidating its hold on power since it legitimates an expansion of its mandate to impose its own order of things on society. Thus, it shifts the balance between the state and society in favour of the former. There are in addition a number of serious implications that this approach brings with it for foreign policy. In order to corroborate these points, let us proceed to examining how the civilisational model is being articulated.

\section{Vladimir Putin's civilisational model}

In one of his articles, Vladimir Putin maintained that "the self-definition of the Russian people is that of a multi-ethnic civilisation [samoopredelenie russkogo naroda - eto polietnicheskaia tsivilizatsiia]" (Putin 2012 b). The critical detail for Putin when defining the nature of this civilisation was the idea of a "state-civilisation" (gosudarstvo-tsivilizatsiia), the existence of which he saw confirmed in Russian history. ${ }^{3}$ Indeed, beginning in 2012, the notion of Russia as being a 'state-civilisation' has been stressed repeatedly in his public texts and talks. To take one example that can stand for many, in his 2012 Address to the Federal Assembly, Putin stated that "we must value the unique experience passed on to us by our forefathers. For centuries, Russia developed as a multi-ethnic nation (from the very beginning), a state-civilisation bonded by the Russian people, Russian language and Russian culture native for all of us, uniting us and preventing us from dissolving in this diverse world" (Putin 2012c).

The crucial importance of the state, it is claimed, has been an essential and inalienable feature of Russian history. Conversely, Russia's identity as a distinct civilisation is seen as the enduring foundation on which the state as a political entity rests. During the 2013 Meeting of the Valdai International Discussion Club, for instance, Putin maintained that "Russia [...] has always evolved [...] as a state-civilisation, reinforced by the Russian people, Russian language, Russian culture, Russian Orthodox Church and the country's other traditional

3 Already in 2009, Marlène Laruelle drew the attention to Mikhail Remizov (b. 1978), a politologist, publicist and conservative thinker, as one of the ideologists behind the notion of a Russian 'state-civilization.' See (Laruelle 2009: 62). 
religions. It is precisely the state-civilisation model that has shaped our state polity" (Valdai 2013).

There are two features evident here that are worthy of note. The first is that the idea of a self-sufficient Russian civilisation ceases to be merely a matter of detached historical and cultural interest and is transformed into a political ideology. Issues concerning culture and values then become major political concerns. It goes without saying that if the state in this connection is envisioned as an upholder of a select cultural programme through which it defines itself and its subjects, this will have great consequences for its cultural policy. It bestows on the state the mission of upholding and defending the traditional cultural values that are believed to be inherent in the civilisational matrix.

The second feature, which follows from the first and is subtly related to it, is that the centrality of the state is inscribed as it were into the civilisational model itself, the main idea being that the state makes up the historical basis of, and is inseparable from, the civilisation in question and has been a key component in how this civilisation has played out in history. The civilisation and the state are envisioned as being so intimately connected as to be practically indistinguishable. In other words, Russian culture is envisioned as being fundamentally state-centric when it is at its most authentic and original. There is an obvious political conclusion to be drawn from this approach and that can best be described as a belief in the primacy of the state, or Statism.

Mention has already been made of Vladimir Putin's preference for Statism as a political philosophy. Statism has been an enduring source of Russian foreign policy-making as well, and not only Putin's. Andrei P. Tsygankov has identified it as one of three "distinct traditions, or schools, of foreign policy thinking" (Tsygankov 2013a), with its own specific preferences and priorities. "Statists," writes Tsygankov, "have emphasized the state's ability to govern and preserve the social and political order." They are "explicit in choosing values of power, stability, and sovereignty over those of freedom and democracy" (Tsygankov 2013a).

Indeed, Vladimir Putin has promoted the idea of a strong Russian state from the very first day of his accession to the presidency. Upon becoming Acting President in 1999, he announced Statism (gosudárstvennichestvo), together with patriotism (patriotizm), great-powerness (derzhavmost), and social solidarity (sotsialnaia solidarnost'), as being the "core values and fundamental ideological reference points" of his proposed "Russian idea [rossiiskaia ideia]" (Putin 1999). In his article, Putin claimed that a Statist political outlook and a reverence for the state is something that is an inalienable feature of the Russian people:

"For us, the state and its institutions and structures have always played an exceptionally important role in the life of the country and the people. For Russians, a strong state is not an anomaly to fight against. Quite the contrary, it is the source and guarantor of order, the initiator and the main driving force of 
any change. [...] Society desires the restoration of the guiding and regulating role of the state" (Hill - Gaddy 2013).

Based on this line of reasoning Putin concluded that "Russia needs a strong state power and must have it" (Hill - Gaddy 2013). Given this background, the strong emphasis that has been put on the state in Putin's civilisational discourse during the last few years should come as no surprise, quite despite the fact that it was articulated at a much later date than were the words just quoted.

The conclusion that can be drawn from this observation is that the so-called 'civilisational turn,' important and consequential as it is in itself, nevertheless has not brought with it any major changes in the fundamental priorities and aspirations that guide the Russian leadership and were already in place prior to this development. In other words, the civilisational turn can be described in terms of enduring preferences and changing strategies. ${ }^{4}$

\section{The Uses of the Civilisational Identity}

If, as it is argued here, the introduction of the civilisational model signifies merely a change in strategy rather than in foundational principles, then the question must be asked wherein the political expediency of it lies, and why the distinct Russian civilisational identity was adopted in the first place. How, in other words, does it help the ruling elite in achieving its Statist goals? To answer this question we will have to examine briefly under what circumstances it arose, starting from the basic assumption that it was part of a concerted effort to deal with specific situational demands to which the government saw itself forced to respond.

Andrei P. Tsygankov has suggested three contexts as relevant for making sense of the 'civilisational turn' in Russian politics: a global one, a regional one, and a domestic one. "Globally, Russia confronts the ongoing efforts by the United States to spread democratization across the world and present Western values as superior to those of the rest of the world" (Tsygankov $2013 \mathrm{~b}$ ). The regional dimension refers to "the fear of radical and militant Islam" (Tsygankov 2013 b). In the domestic context, a number of issues converge. Most important among these are "the growing influence of Islamist ideologies, rising immigration from Muslim-dominated former Soviet republics and desolation on the

4 For a discussion of the distinction that is drawn here between fundamental state preferences and changeable policy strategies, see (Moravcsik 1997). In Moravcsik's view, the underlying societal interests that are represented by powerful domestic groups and corporate agents are crucial in determining which state preferences will come to shape state behaviour on the international arena. To my mind, applying this approach to the case at hand goes a long way in explaining what has taken place during the last few years. In terms of social group, we are dealing, of course, with the powerful so-called siloviki, who generally share among themselves a Statist political outlook. For further details about them, I would like to refer the reader to the research of Olga Kryshtanovskaya and Stephen White (e.g. Kryshtanovskaya - White 2003; Kryshtanovskaya 2008; Kryshtanovskaya - White 2009). 
North Caucasus," which have "created a dangerous environment," with ethnic tensions on the rise (Tsygankov 2013 b).

Tsygankov's thesis about a threefold contextual challenge makes a great deal of sense. An examination of the relevant source texts does on the whole corroborate that the circumstances mentioned by him represent the major conditioning factors that should be taken into consideration when one tries to understand the gradual emergence of the civilisational discourse in Russian politics prior to 2012 .

When it comes to the formulation of Russian civilisational identity that emerged in 2012, and especially Vladimir Putin's rendering of it, however, these three contexts taken by themselves are not enough to account for this development. This latest phase of the 'civilisational turn' is reflective rather of another, more profound, predicament. It is both an outcome of and itself a contributing factor towards a long-term and systemic crisis of liberal democratic values in Russian politics. It is indicative of the failure not only to decisively implement such values, but also is a direct result of the enduring Statist agenda which compromises these values entirely. Rather than explaining these developments as a result of inter-state interaction, then, and as a protective measure taken to counter a belligerent Western-led democracy promotion and moralistic proselytism, it makes more sense to regard it as a result of policy choices made by a small but exceedingly powerful elite grouping at the pinnacle of power.

At the end of the day, we are dealing with a case of regime survival, effected by a regime that can hold on to power and ensure its own continuity only by means of safeguarding its quasi-democratic, unreformed, order. It quite justifiably feels threatened by the prospect of a full implementation of a liberal democratic programme, which would mean having to accept relinquishing power at one time, demands for which have come not only from forces in domestic society but from transnational society as well. During the period leading up to Vladimir Putin's public endorsement of the civilisational identity, there was an increasing urgency in this regard when significant questions were being raised among the general public about the democratic legitimacy of the regime. During 2011, in increasing numbers, the young urban elite took to the streets demanding fair and equal elections. It protested as well against the pre-planned transfer of presidential power from Dmitry Medvedev back to Vladimir Putin and against the authorities' alleged involvement in the electoral rigging that reportedly took place in connection with the Russian legislative elections in late 2011.

In this situation, which in the eyes of the authorities seemed to spell disaster in the form of a 'coloured revolution' finally taking place inside the country, an approach had to be found by means of which it would be possible to discredit and alienate the protesters and those criticising the government, mobilise popular support, and divert people's attention away from the increasingly obvious democratic deficits to a common threat. The latter was artificially brought 
about by references to hidden adversaries, 'foreign agents,' and a 'fifth column,' who purportedly wanted to destabilise the government and generate political chaos, which created a fearful atmosphere and a sense of being under seige. The civilisational model also played its part in legitimating this political course, in which Liberalism became the first casualty.

In fact, the civilisational paradigm challenges liberal values in at least three major ways. First, the idea of multiple civilisations, being based as it is on the notion of a competition between different value systems, makes relative the notion of universality, which lies at the basis of human rights. Second, as a form of nationalism (more about which shall be said presently), the civilisational approach rejects Liberalism on the basis that it represents a value system belonging to an alien culture, which is not to be emulated by Russians. Third, the way it is represented, it offers a rendering of Russian culture and its 'traditional values' which takes hold of the elements in history that have been decidedly non-liberal. Indeed, already in his 1999 article, Putin asserted that "it will not happen soon, if it ever happens at all, that Russia will become the second edition of, say, the US or Britain in which liberal values have deep historic traditions" (Putin 1999).

Thus, in regard to the values dimension, the civilisational approach essentializes differences, and represents in this sense an ideology of separativeness that can be used as a means of self-distinguishing and, concurrently, of othering (two approaches which involve a reifying both of the Self and of the Other). In order to categorize this phenomenon in cases when it touches upon national identity, Emil Pain coined the term 'civilisational nationalism' (Verkhovskii - Pain 2012), which subsequently has been employed by other scholars as well (e.g. Mjør 2012). However self-contradictory as this label might appear at the first glance it actually captures quite well what came to the fore at the top political level in 2012. In the present context, civilisational nationalism can be said to refer to the notion of civilisational diversity in the service of a particularist agenda, that is to say utilised for the purposes of consolidating "society on the basis of concepts of a common historical and cultural essence and to counterpose [one's] own special and unique community to 'foreign' communities" (Verkhovskii - Pain 2012). Thus, at the basis of 'civilisational nationalism,' as it is understood here, there lies an emphasis on cultural distinctiveness and uniqueness. In short, it is a framework which legitimates a Russian Sonderweg (special path).

By means of this approach, the government has created an ideological platform on the basis of which it can stave off efforts at democracy promotion coming from abroad, and stigmatise as stewards of alien powers domestic actors who appeal for political reform. In the international context, it has been called upon to make the domestic political order impervious to foreign critique, and can therefore be said to further a normative resistance, or a defiance against being a norm-taker. In so far as this policy serves to promote the attainment of policy independence, which has been an enduring objective for the regime since at least 
2004 when Russia was semi-officially branded as being a 'sovereign democracy,' this strategy can be said to further the Statist agenda. That perfectly legitimate domestic and transnational societal demands for reform are discredited as being nothing more than the dictates of foreign states gives further witness to the Statist bias against an independent and free civil society.

The Statist priorities shine through as well in the accompanying securitisation of identity, which has been noted by several scholars (e.g. Viatcheslav Morozov and Igor Zevelev). One might recall that "critical to [Russian] Statism is the notion of external threats to Russia's security" (Tsygankov 2013a). In order to strengthen internal political control and to consolidate national unity external threats are magnified and the spectre of a largely hidden enemy is evoked. This policy was palpably present in Vladimir Putin's presidential campaign, and could be felt not least in the allusions that were being made at that time to a looming threat to the civilisational identity itself and its common "cultural code." ${ }^{5}$ Putin claimed, for instance, without specifying how this was being done or by whom, that the Russian 'cultural code' "has been attacked ever more often over the past few years; hostile forces have been trying to break it, and yet, it has survived. It needs to be supported, strengthened and protected" (Putin 2012 b). It is explicitly made clear here that the 'cultural code' is not viewed as self-supporting, but has to be fortified and defended by the state. It might also follow from this argument, based as it is on the notion of a Russian state-civilisation, that a refusal to somehow conform to the cultural values supposedly inherent in the 'cultural code' can be seen as an attack on the state. It goes without saying that this reasoning provides an argument for expanding the mandate of the security services within society, something which according to the findings of Olga Kryshtanovskaya indeed has taken place since Vladimir Putin's return to the presidency (Viktorov 2014).

\section{Consequences for Foreign Policy}

It has already been mentioned that the 'state-civilisation' model of Russian identity would have some important implications for foreign policy. Now, the question naturally arises concerning what its function has been in recent international developments. Although a more qualified answer to this question will have to wait for a future study, I shall attempt a tentative answer this question

5 At times, the terms 'cultural code' and 'civilisational code' have been used interchangeably. This is the case, for instance, in the document entitled Russia's National Policy Strategy through to 2025, which states that "the modern Russian state brings together a single cultural (civilisational) code, based on the preservation and development of Russian culture and language and of the historical and cultural heritage of all the peoples of Russia, which is characterised by a particular striving for truth and justice, respect for the unique traditions of the peoples living in Russia, and by the ability to integrate their best achievements in a single Russian culture" (Strategiia 2012). 
by examining below the role of the official civilisational discourse in the recent Ukraine-Russia conflict.

The first tenet of the civilisational model that has been instrumentalised in the Ukrainian crisis is that of the existence of mutually exclusive civilisational units. This has implied drawing up dividing lines between Russia and the monolithic West, the result of which is to foster a new kind of bloc thinking. For instance, in an article published on 13 February 2014, that is to say roughly one week before Viktor Yanukovich abandoned the capital of Kiev, Sergey Lavrov referenced what Samuel P. Huntington had written on Ukraine. He then called attention to the idea of Ukraine as being a country that strides the fault line between two different civilisations, something which makes it difficult for the country's leadership to decide in what main direction to turn when it comes to its foreign relations.

"If one examines the history of independent Ukraine, it becomes clear that all attempts to swiftly and 'in one fell swoop' determine the vector of the country's foreign relations - to the West or to the East - invariably have ended in failure. [...] Strictly speaking, the 'texture' of the Ukrainian society does not allow it to 'swing' one way or the other. Already twenty years ago Samuel Huntington wrote about this in his Clash of Civilizations, warning that any attempt to determine this issue would be a factor tearing domestic relations in the Ukrainian state apart, with potentially dire consequences for the country" (Lavrov 2014).

The intention behind this reference to Huntington's idea of Ukraine as a 'cleft country' was of course to bolster the Russian government's opinion that Ukraine should remain a neutral and non-aligned country and not be allowed to join either the EU:s Eastern Partnership programme, for which the Ukrainian opposition fought, or NATO.

Later in the year, the Russian President intriguingly also picked up this Huntingtonian idea of Ukraine as being divided between two civilisations, although he made reference to it in a slightly less direct manner than Lavrov had done before him. In his speech at the 2014 Meeting of the Valdai International Discussion Club, Vladimir Putin had the following to say:

"Today, we already see a sharp increase in the likelihood of a whole set of violent conflicts with either direct or indirect participation by the world's major powers. And the risk factors include not just traditional multinational conflicts, but also the internal instability in separate states, especially when we talk about nations located at the intersections of major states' geopolitical interests, or on the border of cultural, historical, and economic civilisational continents [na granitse kul'turno-istoricheskikh, ekonomicheskikh, tsivilizatsionnykh 'materikov']. Ukraine [...] is one of the examples of such sorts of conflicts that affect [the] international power balance, and I think it will certainly not be the last" (Valdai 2014).

Here we can see Vladimir Putin's acceptance of Sergey Lavrov's long-standing theory of a tectonic shift taking place in the global political landscape and the 
increasing importance of economically, politically and culturally defined poles or centres of power. Noteworthy as well is the manner in which the idea of multiple civilisations is interwoven with the geopolitical discourse, which of course experienced a peak in popularity during the Ukrainian crisis.

The next point to be mentioned here has reference to the civilisational identity itself. Although 'state-civilisation' is the privileged designation to which the civilisational identity refers in this case, it does not follow that it represents a civic identity. To the contrary, it is a cultural identity that designates membership in a cultural community. This makes the civilisational identity significantly vaguer and more difficult to handle politically and administratively than the civic identity, which is formalised as citizenship. On the other hand, it offers more freedom of manoeuvre for a political actor who needs a malleable formula for identity that contains an element of uncertainty and is open for interpretation.

In the Ukrainian crisis, such has been the function of the concept of 'compatriots' or 'co-nationals' (sootechestvenniki), which has been crucial for the Russian government in legitimating Russia's incursions into the Ukraine. It provided an argument as to why foreign citizens, even though they hold a non-Russian citizenship, nevertheless are entitled to protection by the Russian state. The translations that have figured in the English-speaking media, such as 'ethnic Russians,' 'Russophones' or Russian-speakers,' do not do justice to it, since it is not in the first place based on such 'objective' criteria (linguistic, ethnic or otherwise), but on (inter-)subjective ones, most important among which is a shared sense of community with Russian culture. Admittedly, Russian 'compatriots' can be both ethnic Russians and/or Russophones, but none of these factors are ultimately decisive for deciding who belongs to this category. What is decisive, though, is the Russian authorities' self-appointed right to decide who belongs to the community of Russian 'compatriots' based on a very loose and permitting definition. In 2014, at an annual reception organised on behalf of newly appointed foreign ambassadors to Russia, Vladimir Putin was quite outspoken about this. In fact, he used 'compatriots' and 'Russian people' (russkie liudi) interchangeably, thus implying that his understanding of Russian identity itself, and of the Russian state's so-called right to protect, would not be limited only to citizens of the Russian Federation.

"In Ukraine, as you may have seen, at threat were our compatriots [sootechestvenniki], Russian people [russkie liudi] and people of other nationalities, their language, history, culture and legal rights, guaranteed, by the way, by European conventions. When I speak of Russians [russkie liudi] and Russian-speaking citizens I am referring to those people who consider themselves part of the broad Russian community [tak nazyvaemyi shirokii russkii mir], they may not necessarily be ethnic Russians, but they consider themselves Russian people [shchitaiut sebia russkim chelovekom]" (Putin 2014a). 
At a later date, during the latest round of his annual televised marathon interview, Vladimir Putin returned to this issue. He reiterated once again that the compatriot identity was principally a cultural one, and that the ultimate criterion for having such an identity was subjective, that is to say would have to be based on self-identification.

"At this point, Russia is not expecting anything from Kiev officials except one thing. They must see us as equal partners in all aspects of cooperation. It is also very important that they observe the legitimate rights and interests of Russians living in Ukraine and those who consider themselves Russian regardless of what their passports say. People who consider Russian their mother tongue and Russian culture their native culture. People who feel an inextricable bond with Russia. Of course, any country cares about people who treat it as their motherland (in this case, Russia). This is nothing extraordinary" (Putin 2015).

This line of reasoning ties in with what was said above about the conviction that the Russian state is tasked with defending the members of the larger cultural community that is the 'Russian world.' It deserves mention here that the 'Russian world' is one of the several designations that have been used during recent years to brand the Russian civilisation. In many ways, it is a natural outgrowth of the civilisational discourse. Yet, in terms of usage and in the purpose attached to it there are also certain specifics. The 'Russian world' concept was co-opted by the Russian government as a means of reaching and attracting the Russian diaspora, and also as part of an effort to enhance its soft power abroad. The fact remains, though, that the authorities at times have explicitly framed the 'Russian world' concept in civilisational terms, as the following quotation of Sergey Lavrov makes clear: "I think everyone will agree that the priority efforts of the state and civil society is to further promote the concept of the 'Russian World' as a civilisational and cultural space, which unites people of different nationalities who are not indifferent to the fate and place of Russia in the world" (Lavrov 2014 b). ${ }^{6}$

Lastly, it deserves mention that the civilisational model bestows on the Russian authorities an even more elevated mission, which transcends its role as a regional power. In the already quoted speech given to the newly installed ambassadors to Russia, Putin would bring up the idea of Russia as a defender of global civilisational diversity, rising to the occasion to defend against the alleged attempt by some major world powers to force their own order on others:

"There is hardly any doubt that the unipolar world order did not come to be. Peoples and countries are raising their voices in favour of self-determination and civilisational and cultural identity [tsivilizatsionnaia $i$ kulturnaia identichnost'], which conflicts with the attempts by certain countries to maintain their

6 For a more qualified discussion of the uses of the 'Russian world' concept, see (Laruelle 2015). 
domination in the military sphere, in politics, finance, the economy and in ideology" (Putin 2014a).

Again we are confronted with an attempt at safeguarding Russia's policy independence, with the securitisation of cultural identity, and with the view that the fight against a Western-led globalisation is a righteous cause. Of course, the entire official Russian political discourse during the Ukrainian crisis has been defined by a highlighting of matters pertaining to defense and security. The cultural and civilisational dimensions of Russian national identity have been instrumentalised in order to amplify this argument. One should not underestimate the importance of this strategy for gaining a hearing with a domestic audience. In the imagination of many Russians, and non-Russians as well, the conflict surrounding the Ukraine has taken on the proportions of a full-blown clash of civilisations, as prophesied at one time by Samuel P. Huntington, with the notable difference that Russia is battling not only for its own sake but for all non-Western civilisations' who want to exist independently. And the authorities have played their part in bringing this conviction about. During a press conference held on 18 December 2014, Vladimir Putin summarised Russia's involvement in the Ukraine crisis and the country's present economic hardships as the result of its rightful wish to continue to exist as a separate civilisation:

"ANTON VERNITSKY, CHANNEL ONE RUSSIA: Mr President, are the current economic developments the price we have to pay for Crimea? Maybe the time has come to acknowledge it?

VLADIMIR PUTIN: No. This is not the price we have to pay for Crimea... This is actually the price we have to pay for our natural aspiration to preserve ourselves as a nation, as a civilisation, as a state" (Putin 2014 b).

\section{Conclusion}

In the present essay, a brief examination has been made of the recent 'civilisational turn' in Russian political discourse. Based on the observation that what distinguishes Vladimir Putin's rendering of Russian civilisational identity is its strongly emphasized state-centrism, the argument has been advanced that the Russian 'civilisational nationalism' is first and foremost motivated and driven forward by aspirations integral to a previously consolidated political outlook, the first articulation of which can be traced back to the very beginning of the present decision-making community's assumption of power at the turn of the millennium. It has furthermore been argued that this development is also the outcome of a systemic crisis that has come about as a result of the strategic choices made on the basis of this Statist position. To be more specific, 'civilisational nationalism' has been called forth and shaped by a combination of a Statist political outlook, inherited from Soviet times but adapted to Rus- 
sia's post-imperial condition, and of situational policies adopted as responses to a set of pressing challenges relating to the increasing deficit of liberal democratic values in the Russian political system.

The political expediency for the present regime of a self-contained Russian civilisational identity is also better understood if it is brought into relation with the Statist agenda. It bestows on the state the domestic civilising mission of upholding and defending the traditional cultural values supposedly inherent in the civilisational matrix, thus providing a formula for an identity politics that suits the authorities well. At the same time, the influence of foreign cultures on Russia can be limited on the basis of it, since it can be argued that they spread values that are not only alien, but potentially detrimental to the integrity of the Russian 'cultural code.'

There have been some important repercussions for foreign policy-making as well. When it comes to regional affairs, Russia is attempting to legitimate its involvement abroad on civilisational grounds. The loose definition of 'compatriots' as foreign nationals experiencing some affinity with Russia gives it plenty of leeway in this regard. Furthermore, Russia has petitioned for Ukraine's neutrality and status as a nonaligned party based on the argument that the country is straddling a civilisational fault line. In relation to the West, there is an attempt to counteract its globalistic agenda by depicting the liberal values that it attempts to spread as less than universal.

From what has been said above it should be quite clear how the described ideology sits well with a regime that is increasingly intent on defending its own illiberal positions. The ruling elite has taken on itself the mission of preserving intact its semi-democratic political system, dubbed alternatively "electoral authoritarianism" or "managed democracy," against the onslaught not only of domestic demands for reform, but also of the imperatives that the increasingly interconnected global community is bringing with it. It imagines itself as positioned on the summit of a paternalistic and values-based state hierarchy, which is encircled by hostile forces and that towers over a domestic civil society that is circumscribed to the degree demanded by it. Despite the fine words of cultural self-determination and the importance of indigenous values, what has really happened is that the ruling elite has co-opted Russian culture for its own political purposes and has taken on itself the task of deciding who belongs to the Russian community and who does not.

\section{References}

Hill, Fiona - Gaddy, Clifford G. (2013): Mr. Putin: Operative in the Kremlin, Brookings Institution Press. 
Kryshtanovskaya, Olga - White, Stephen (2003): Putin's Militocracy. Post-Soviet Affairs 19 (4): 289-306.

Kryshtanovskaya, Olga (2008): The Russian Elite in Transition. Journal of Communist Studies and Transition Politics 24 (4): 585-603.

Kryshtanovskaya, Olga - White, Stephen (2009): The Sovietization of Russian Politics. Post-Soviet Affairs 25 (4): 283-309.

Laruelle, Marlène (2009): Inside and Around the Kremlin's Black Box: The New Nationalist Think Tanks in Russia, Institute for Security and Development Policy.

Laruelle, Marlène (2015): The "Russian World": Russia's Soft Power and Geopolitical Imagination, Center on Global Interests.

Lavrov, Sergei (2014a): 'V ponimanii ES i SShA 'svobodnyii' vybor za ukraintsev uzhe sdelan.' Kommersant (13 February).

Lavrov, Sergei (2014 b): Vystuplenie Ministra inostrannykh del Rossii S. V. Lavrova na vstreche s predstaviteliami rossiiskikh nepravitel'stvennykh organizatsii mezhdunarodnoi spetsializatsii: Available at http://archive.mid.ru//bdomp/brp_4.nsf/2fee282eb6df40e643256999005e6 e8c/1f9973ca66ef653e44257cb7003ba7a4!OpenDocument (13 October 2015).

Meeting of the Valdai International Discussion Club (2013): available at http://eng.kremlin.ru/ news/6007 (6 July 2015).

Meeting of the Valdai International Discussion Club (2014): available at http://eng.kremlin.ru/ transcripts/23137 (6 July 2015).

Mjør, Kåre Johan (2012): Ein unik sivilisasjon: Russlandsførestellingar før og no. Nytt norsk tidsskrift 29 (3): 237-247.

Moravcsik, Andrew (1997): Taking Preferences Seriously: A Liberal Theory of International Politics. International Organization 51 (4): 513-53.

Putin, Vladimir (1999): Rossiia na rubezhe tysiacheletii. Nezavisimaia gazeta (30 December).

Putin, Vladimir (2012a): Russia Muscles Up: The Challenges We Must Rise to Face. Izvestiia (16 January): available at http://archive.premier.gov.ru/eng/events/news/17755/ (6 July 2015).

Putin, Vladimir (2012 b): Russia: The Ethnicity Issue. Nezavisimaia gazeta (23 January): available at http://archive.premier.gov.ru/eng/events/news/17831/ (6 July 2015).

Putin, Vladimir (2012c): Address to the Federal Assembly: available at http://en.kremlin.ru/ events/president/news/17118 (6 July 2015).

Putin, Vladimir (2014a): Conference of Russian ambassadors and permanent representatives (1 July): available at http://en.kremlin.ru/events/president/news/46131 (6 July 2015).

Putin, Vladimir (2014 b): News conference of Vladimir Putin (18 December): available at http:// eng.kremlin.ru/transcripts/23406 (6 July 2015).

Putin, Vladimir (2015): Direct Line with Vladimir Putin: available at http://en.kremlin.ru/events/ president/news/49261 (6 July 2015).

Strategiia gosudarstvennoi natsional'noi politiki Rossiiskoi Federatsii na period do 2025 goda (2012): available at http://kremlin.ru/acts/bank/36512 (6 July 2015). 
Tsygankov, Andrei P. (2013a): Russia's Foreign Policy: Change and Continuity in National Identity, Rowman \& Littlefield Publishers, Inc.

Tsygankov, Andrei P. (2013 b): Vladimir Putin's Civilizational Turn. Russian Analytical Digest 127: 5-7.

Verkhovskii, Aleksandr - Pain, Emil (2012): Civilizational Nationalism: The Russian Version of the 'Special Path.' Russian Politics and Law 50 (5): 52-86.

Viktorov, Ilja (2014): The Legacy of Tandemocracy: Russia's Political Elite During Putin's Third Presidency: Interview with the Sociologist Olga Kryshtanovskaya. Baltic Worlds 7 (2-3): 14-21.

Zlobin, Nikolai (2012): Tsena voprosa. Kommersant (6 December).

Fabian Linde is a Postdoctoral Researcher at the Uppsala Centre for Russian and Eurasian Studies (UCRS) in Sweden, who specializes in Russian intellectual history. He received his, Ph.D. in Slavic Languages and Literatures from Stockholm University in 2011. His doctoral thesis, entitled The Spirit of Revolt: Nikolai Berdiaev's Existential Gnosticism, was a re-examination of Gnostic themes in the thought of the Russian Existentialist philosopher Nikolai Berdiaev. At present, Linde is the principal investigator in a project financed by the Swedish Research Council entitled State Civilisation: The Eurasian Union and the Making of a Russian Civilisational Identity, which examines the Russian political leadership's discursive constructions of a Russian civilisational identity and how they relate to foreign policy. E-mail: fabian.linde@ucrs.uu.se. 